\title{
Histological diagnosis of carcinoma of the parathyroid gland
}

\author{
JF SMITH, RRH COOMBS \\ From the Department of Morbid Anatomy, The Medical School, Clinical Sciences Faculty, University College, \\ London WC1
}

SUMMARY During the period 1950-81, 678 cases of primary hyperparathyroidism were surgically treated at University College Hospital, London. The causes were a single adenoma in 575, two adenomas in 25 , carcinoma in 20 (two of which had coexistent adenomas), chief cell hyperplasia in 56, and water clear cell hyperplasia in two. Histological diagnosis is not difficult except in some cases of carcinoma and in a few in which differentiation between recurrent hyperplasia and recurrent carcinoma is exceptionally difficult. In this paper we review all the cases of primary carcinoma of the parathyroid seen during this period to define those pathological features of value in the diagnosis.

Two cardinal features for diagnosis of carcinoma at any site are local invasion and metastasis. In time, consistent association of certain macroscopic and histological features in a particular organ with this behaviour pattern may be used to diagnose carcinoma before infiltration and metastases have occurred. This approach has presented some difficulty with carcinoma of the parathyroid because it is uncommon and few people have the opportunity to study adequate numbers themselves. Moreover, metastasis is rare in carcinoma of the parathyroid. Further, although local recurrence may indicate a carcinoma, it may also occur because hyperplasia of all four parathyroids has been insufficiently resected. Again, although the typical adenoma and the typical carcinoma are quite distinct in their features, some tumours are difficult to categorise.

In the AFIP Fascicle in 1952' the importance of mitoses, a trabecular architecture, adherence to surrounding tissues, and to some extent capsular invasion and the extension of fibrous trabeculae from the capsule into the tumour were emphasised in the diagnosis of carcinoma. In the revised Fascicle in $1978,{ }^{2}$ in addition to these features, the grey-tan colour, the hard consistency, and the lobulated cut surface of many carcinomas were emphasised. ${ }^{2}$ The presence of mitoses within parenchymal cells was considered the single most valuable microscopic criterion, while cellular atypia and variation were not.

\section{Material and methods}

Histological sections from all cases of hypere parathyroidism surgically treated at University Col? lege Hospital, London, were available, together with clinical records for the period 1950-81. In most cases the initial frozen section examinations had been done by one of us (JFS) as well as the gross tissue descriptions and examination of paraffin sections stained with haematoxylin and eosin and other methods when appropriate. In particular, 19 of the 20 cases diagnosed as carcinoma had been examined personally.

The case records and the follow up were supervised by the late Professor Charles Dent and Dr Lyal Watson. The operations were performed by $\mathrm{Mr}$ DR Davies and Mr AG Cowie. We are grateful to them and have indicated the case numbers of patients in the University College Hospital series as these are used in other publications in parathyroid disease from this hospital.

\section{CRITERIA FOR THE DIAGNOSIS OF CARCINOMA OF THE PARATHYROID}

Each lesion was assessed for the presence or absence of a firm macroscopic tumour with a fibrous capsule or fibrous trabeculae, or both, on low power microscopy, a trabecular or rosette like cellular architecture, and the preser,ce of mitoses. These four principal morphological criteria were supplemented by 
Table 1 Pathological features of carcinomas

\begin{tabular}{|c|c|c|c|c|c|c|c|c|}
\hline Group & Case no & Consistency & $\begin{array}{l}\text { Fibrous trabeculae } \\
\text { and capsule* }\end{array}$ & $\begin{array}{l}\text { Histological } \\
\text { architecture }\end{array}$ & Mitoses $\dagger$ & $\begin{array}{l}\text { Local } \\
\text { infiltration }\end{array}$ & $\begin{array}{l}\text { Local } \\
\text { recurrence }\end{array}$ & Metastases \\
\hline A & $\begin{array}{r}3(65) \\
6(169) \\
13(325) \\
19(619)\end{array}$ & $\begin{array}{l}\text { Firm } \\
\text { Not known } \\
\text { Not known } \\
\text { Firm }\end{array}$ & $\begin{array}{l}++ \\
+ \\
++\end{array}$ & $\begin{array}{l}\mathrm{T} \\
\mathrm{T} \& \mathrm{R} \\
\mathrm{T} \\
\mathrm{T}\end{array}$ & $\begin{array}{l}+ \\
+ \\
+ \\
++\end{array}$ & $\frac{+}{+}$ & $\begin{array}{l}+ \\
+ \\
+ \\
+\end{array}$ & $\begin{array}{l}+ \\
+ \\
+ \\
+\end{array}$ \\
\hline B & $\begin{array}{r}1 \\
2(15) \\
4(114) \\
10(266) \\
11(278) \\
12(321) \\
15(454) \\
17(573)\end{array}$ & $\begin{array}{l}\text { Firm } \\
\text { Firm } \\
\text { Firm } \\
\text { Firm } \\
\text { Firm } \\
\text { Firm } \\
\text { Firm } \\
\text { Firm }\end{array}$ & $\begin{array}{l}++ \\
++ \\
++ \\
++ \\
++ \\
++ \\
++ \\
++\end{array}$ & $\begin{array}{l}\mathrm{T} \\
\mathrm{T} \\
\mathrm{T} \\
\mathrm{T} \\
\mathrm{T} \\
\mathrm{T} \& \mathrm{R}\end{array}$ & $\begin{array}{l}++ \\
+ \\
+ \\
+ \\
++ \\
+ \\
+\end{array}$ & $\begin{array}{l}+ \\
+ \\
+ \\
+ \\
+ \\
+ \\
+ \\
+\end{array}$ & $\begin{array}{l}+ \\
= \\
\frac{-}{+} \\
\frac{+}{+}\end{array}$ & $\begin{array}{l}z \\
z \\
z \\
z\end{array}$ \\
\hline C & $\begin{array}{r}5(165) \\
7(176) \\
8(197) \\
9(208) \\
14(421) \\
16(550) \\
18(591) \\
20(632)\end{array}$ & $\begin{array}{l}\text { Not known } \\
\text { Firm } \\
\text { Not known } \\
\text { Firm } \\
\text { Firm } \\
\text { Firm } \\
\text { Firm } \\
\text { Firm }\end{array}$ & $\begin{array}{l}\text { Not known } \\
++ \\
+ \\
- \\
++ \\
+ \\
++ \\
++\end{array}$ & $\begin{array}{l}\mathrm{T} \\
\mathrm{T} \\
\mathrm{T} \& \mathrm{R} \\
\mathrm{T} \\
\mathrm{T} \& \mathrm{R} \\
\mathrm{T} \& \mathrm{R} \\
\mathrm{T} \\
\mathrm{T}\end{array}$ & $\begin{array}{l}+ \\
++ \\
+ \\
++ \\
++ \\
+ \\
+ \\
+\end{array}$ & $\begin{array}{l}z \\
= \\
z \\
z\end{array}$ & $\begin{array}{l}+ \\
+ \\
+ \\
- \\
- \\
-\end{array}$ & $\begin{array}{l}z \\
z \\
z \\
z\end{array}$ \\
\hline
\end{tabular}

Numbers in parentheses indicate the number in the University College Hospital series of operated hyperparathyroid patients.

$*+=$ distinct; $++=$ conspicuous; $-=$ absent.

T\& $\mathbf{R}=$ trabecular or rosette architecture in some areas.

$\dagger+=$ found after searching; $++=$ easily found.

cytological assessment, by search for vascular invasion with the tumour, and occasionally by electron microscopy. Besides these structural features, the neoplastic nature of the lesion has been judged by its behaviour: local invasion in the initial tumour, local recurrence, and distant metastasis.

Those cases diagnosed as carcinoma either showed initial local invasion and subsequently developed metastases or showed three of the four principal morphological features in the initial tumour. In one case (case 5) the initial lesion was not available for study but recurred twice locally. The above morphological features were present in the recurrent tumour.

\section{Results}

The pathological and behavioural features of the tumours are summarised in Table 1.

\section{PATHOLOGY}

\section{Macroscopic features}

Nearly all carcinomas are firm or even hard compared with adenomas, which are usually soft. They are usually greyish white compared with the buff or tan colour of many adenomas. Adherence to surrounding tissue is common (Fig. 1), but this may occur with adenomas, particularly if there has been old haemorrhage or previous surgery. Invasion of surrounding tissue is indicative of carcinoma. In the 14 cases for which we have a record of the initial tumour weight, it varied from $1 \mathrm{~g}$ to $15 \mathrm{~g}$, with a mean of $7 \cdot 3 \mathrm{~g}$. The range was less than that for our adenomas $(50 \mathrm{mg}$ to $37 \mathrm{~g}$ ), but in these the mean weight was much less than in carcinomas.

\section{Microscopical features: fibrous capsule and fibrous trabeculae}

This appearance is commonly seen on low power examination (Fig. 2). It at once arouses the suspicion of carcinoma if the capsule and trabeculae splitting up the tumour tend to be of dense hyaline fibrous tissue similar to that seen in many thymomas. If the dense fibrous tissue is associated with evidence of old haemorrhage or previous surgery, however, it may be a feature of an adenoma; trabeculae of loose fibrous tissue intersecting the tumour may also be found in adenomas.

\section{Architecture}

This is variable in different parts of the tumour. A large sheet of homogenous cells may occur, similar to that in many adenomas. Isolated as nodules within fibrous trabeculae, however, there are often areas of rather uniform but larger cells with a trabecular architecture (Fig. 3) or a pseudorosette pattern (Fig. 4), in which cells are orientated in a regular fashion around thin walled blood vessels or central non-cellular areas. Either of these patterns is suggestive but not diagnostic of carcinoma. It is rare to see trabeculae of carcinoma cells infiltrating fibrous tissue in a comparable way to that seen in scirrhous carcinoma of the breast. Infiltration of the thyroid is a clear indication of malignancy (Fig. 5). 


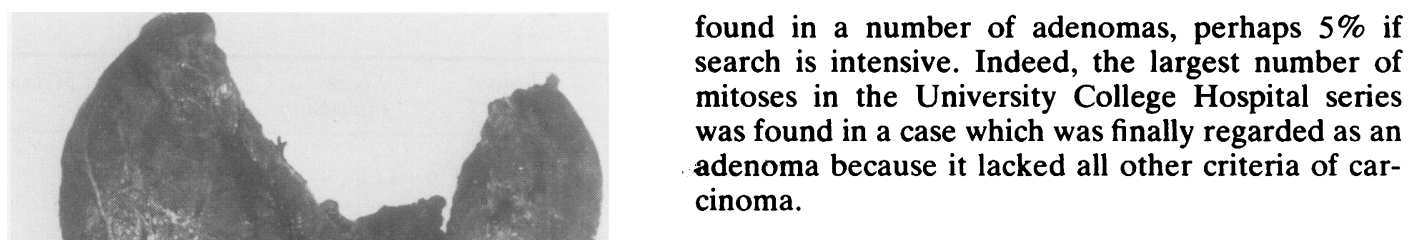
cinoma.

\section{Cytology}

In carcinomas as a whole cells are larger than in adenomas, but there is an overlap in cell size (Lloyd HM, personal communication). The nuclear to cytoplasmic ratio is greater and nucleoli are more distinct in most cells. The cytoplasm is sometimes clear, sometimes amphophilic, and occasionally somewhat oxyphilic; there is often a mixture of cells with different cytoplasm in different areas of the tumour. The nuclei may overlap one another, and, although this may be found in adenomas, such an appearance raises the suspicion of carcinoma when such nuclei have prominent nucleoli (Fig. 7). The "melon seed" cells and nuclei described in the AFIP Fascicle raise a similar suspicion (Fig. 8). The largest cells and the most atypical nuclei by conventional standards are found in a minority of adenomas (Fig. 9) and were, in fact, present in the adenomas which were removed at different sites in cases 7 and 12 of the present series in which carcinomas were resected. Furthermore, in both these cases the carcinomas recurred a few years later at the site of removal with similar features, but there was no? recurrence of the adenomas.

\section{Vascular invasion}

This is occasionally seen in carcinoma, but we have also seen it once in a large tumour which by all other criteria was an adenoma (Fig. 10) and have not therefore considered it a diagnostic feature. Extension into vessels is sometimes seen in other endocrine neoplasms-for example, phaeochromocytoma-without being considered indicative of malignancy.

\section{Electron microscopy}

We think that the nuclear features described in some of the earlier cases of this series ${ }^{3}$ and by others ${ }^{4}$ are useful. Unfortunately, only three of the later cases in this series have been examined in this way. In two the chromatin pattern of electron dense clumps dispersed through the karyoplasm, colloquially known as "an angry nucleus", was present. We have never seen these in an adenoma. In the other case such nuclei were not identified, but interchromatin granules described in malignant nuclei in other diseases were seen. ${ }^{5}$ Our experience with this change, however, is insufficient to assess its importance in parathyroid pathology. 


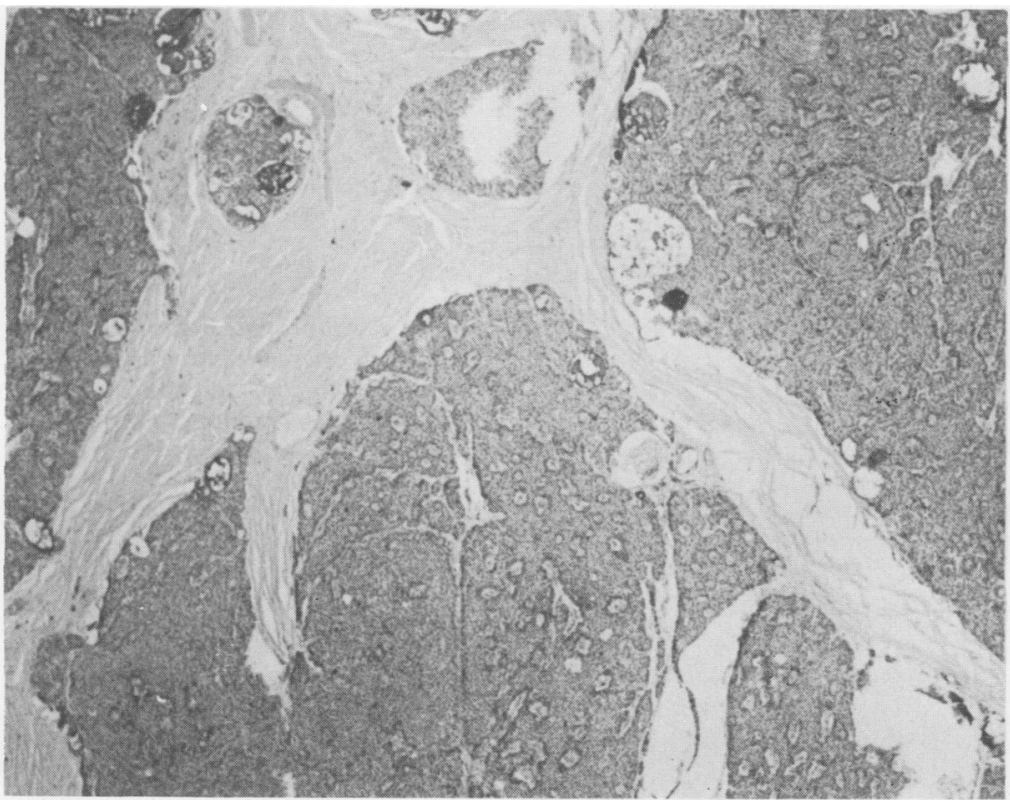

Fig. 2 Dense hyaline fibrous trabeculae extending from the capsule to split the carcinoma into islands are a characteristic feature. Case 20. Haematoxylin and eosin $\times 80$.

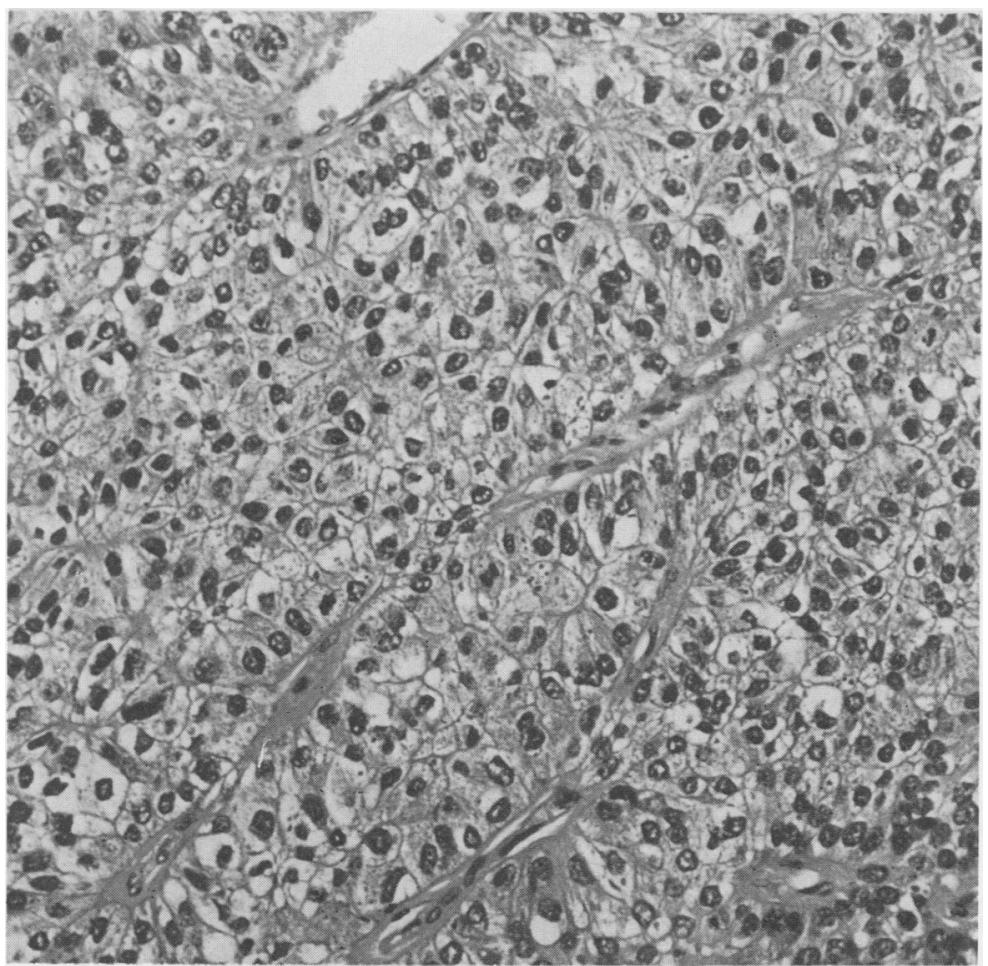

Fig. 3 Trabecular architecture of a carcinoma. Case 12. Haematoxylin and eosin $\times 128$ 


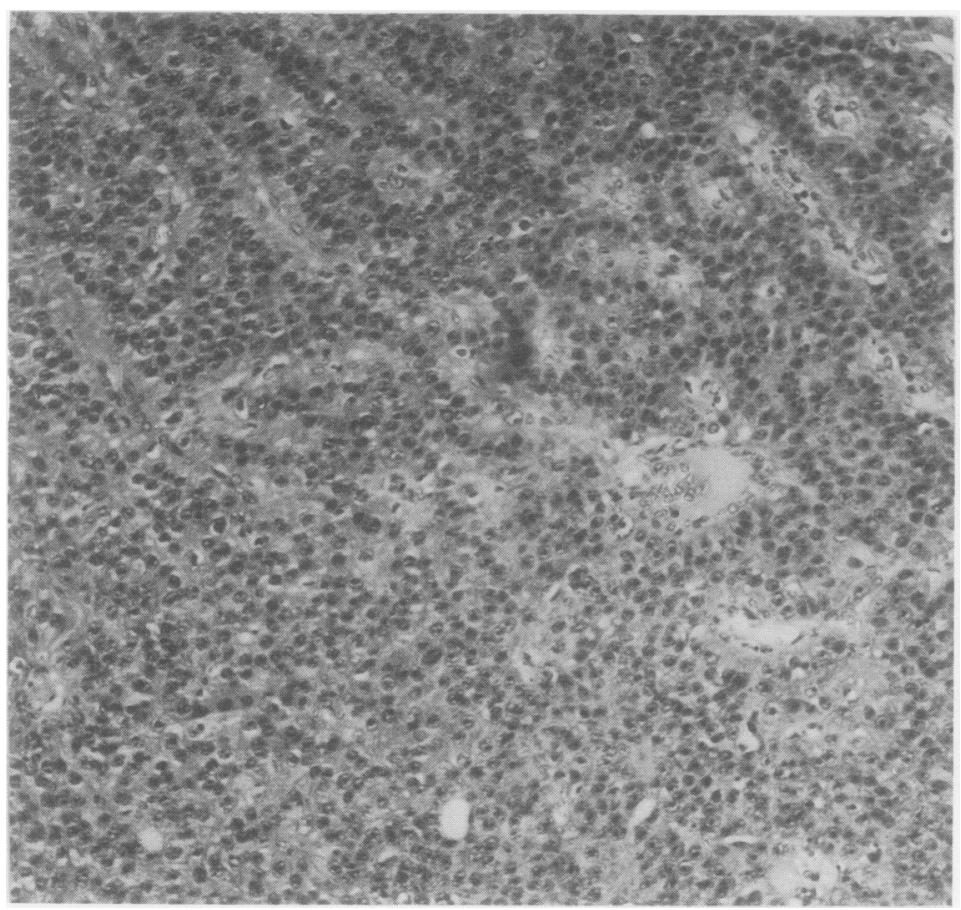

Fig. 4 Pseudorosette pattern. This, like the trabecular architecture (Fig. 3), should lead to consideration of the possibility of a carcinoma. Case 16. Haematoxylin and eosin $\times 128$.

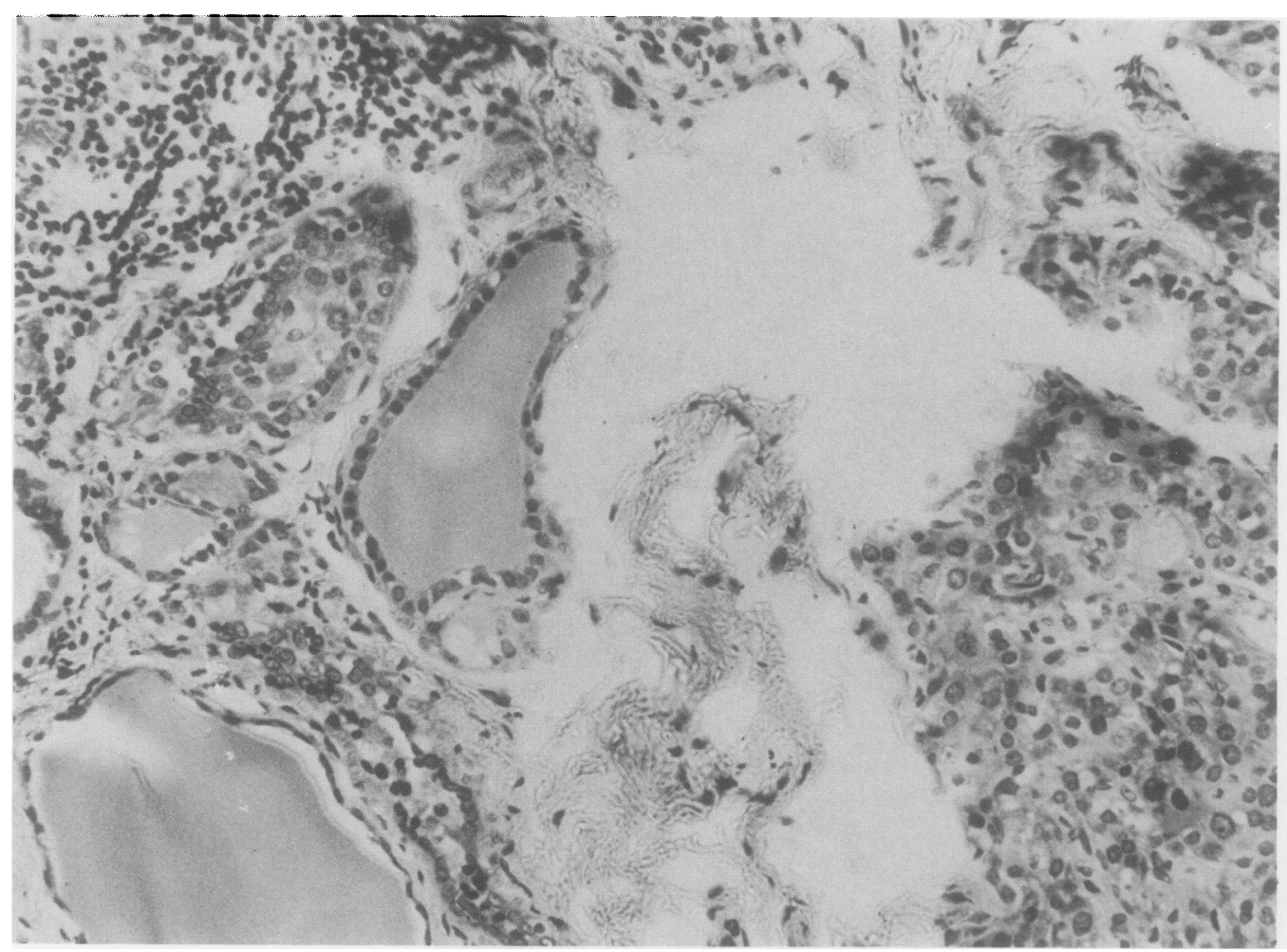

Fig. 5 Infitration of thyroid by a parathyroid carcinoma, invading from the left and between thyroid acini. Case 4. Haematoxylin and eosin $\times 128$. 


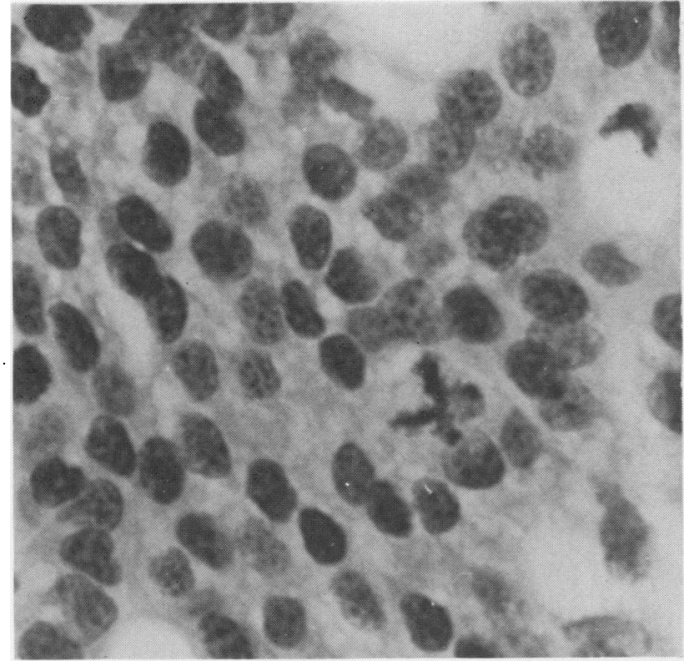

Fig. 6 Tripolar mitosis in carcinomatous area in a tumour which was possibly an adenoma initially. Case 9.

Haematoxylin and eosin $\times 560$.

\section{BEHAVIOUR}

These data were assembled at first with cases in chronological order $(1-20)$, but they have been tabled in three groups reflecting the clinical course: group $A$ includes the four cases in which metastasis developed; group B includes the eight cases in which local invasion was present in the initial specimen; and group $C$ includes the remaining eight cases in which distant metastasis has not occurred to date and in which there was not initial invasion. Three of the cases in group $\mathrm{C}$ have recurred locally, however, and only two of the remaining five have been fol- lowed up for more than five years.

The occurrence of the four main morphological criteria is the same in each behaviour group. This supports the view that these criteria may be used, with care, in making a diagnosis of carcinoma before local invasion or metastasis has occurred.

The following points are of major interest and require emphasis: in all cases where observation of the initial gross tumour was possible, it was firm or hard. Fibrous trabeculae and a fibrous capsule were present in 18 of the 20 tumours and prominent in 14; this feature was absent in only one case in group $A$ and one in group C. A trabecular architecture was present to some extent in 19 of the 20 cases and accompanied in some areas by a rosette pattern in five; the only case in which a trabecular architecture was absent was in group B. Mitoses were found in all cases except case 2 in group B; they were not more numerous in cases with initial local infiltration or which metastasised.

\section{CLINICAL FOLLOW UP AND ILLUSTRATIVE CASE REPORTS}

The clinical course of the disease was often prolonged after the initial diagnosis and a summary is provided in Table 2 . Nearly all cases presented with a picture of rapidly developing hyperparathyroidism with raised serum calcium concentrations and clinical bone disease. Two illustrative cases are briefly reported; case 4 is exceptional in lacking evidence of bone disease.

\section{Case 4}

A 62 year old man had had painless haematuria due to renal calculi 18 months before admission to Uni-

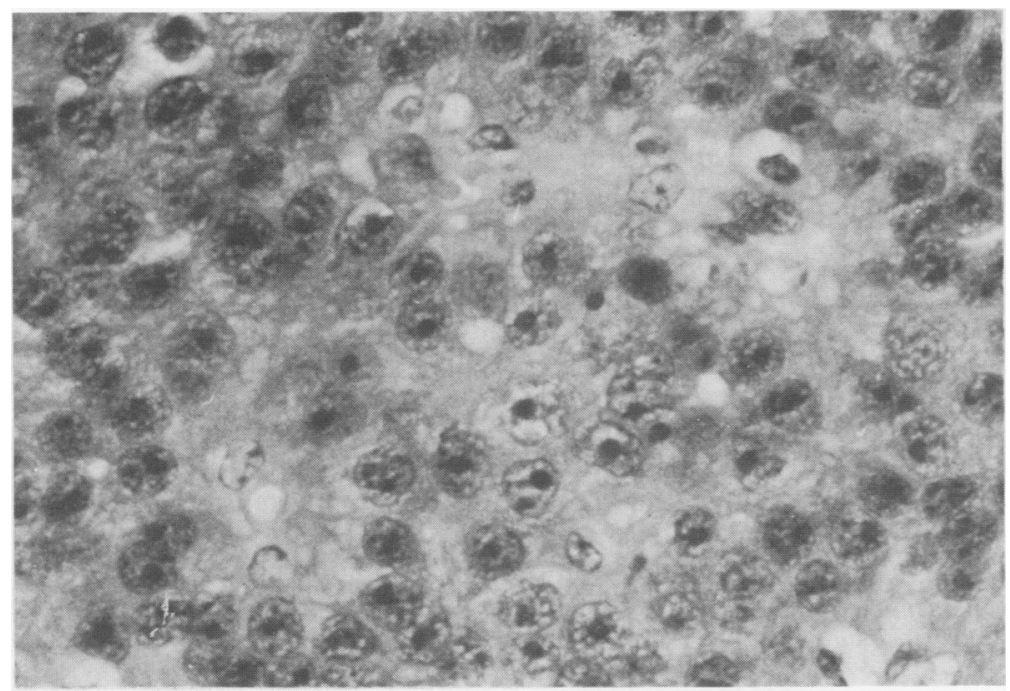

Fig. 7 Prominent nucleoli in large overlapping nuclei; again this feature raises the possibility of carcinoma but is not diagnostic. Case 16. Haematoxylin and eosin $\times 500$. 


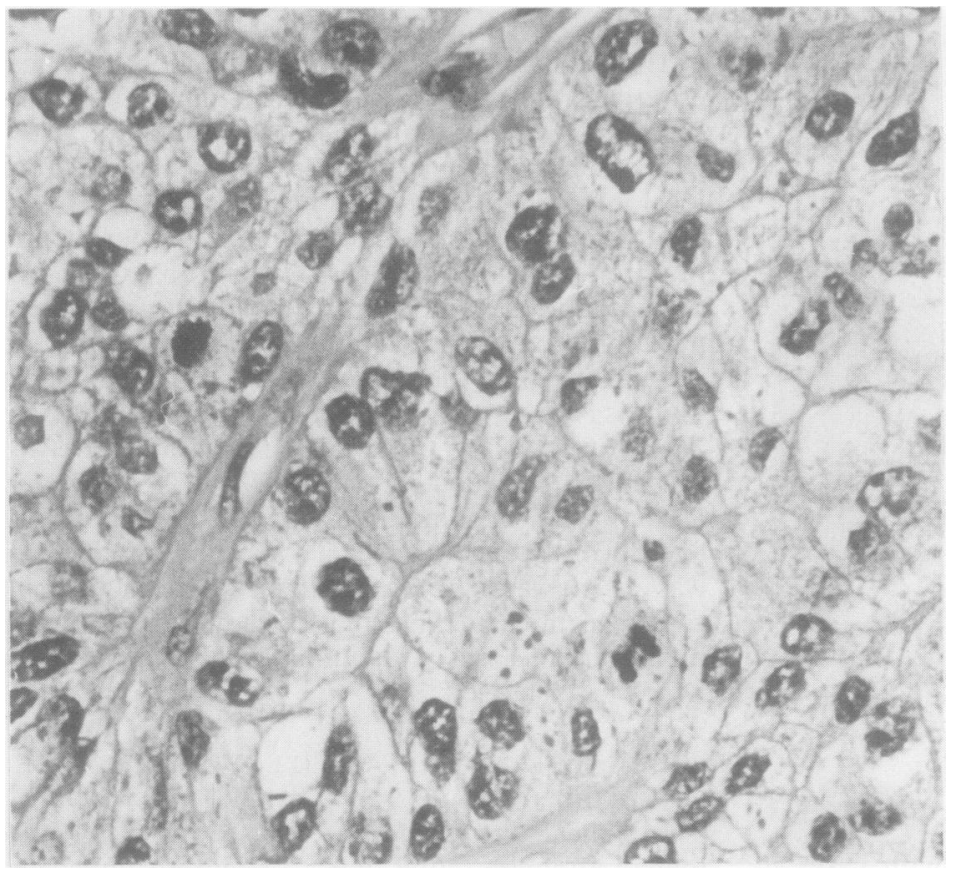

Fig. 8 Melon seed like nuclei and cells. Two mitotic figures are in this field.

Case 12. Haematoxylin and eosin $\times 320$.

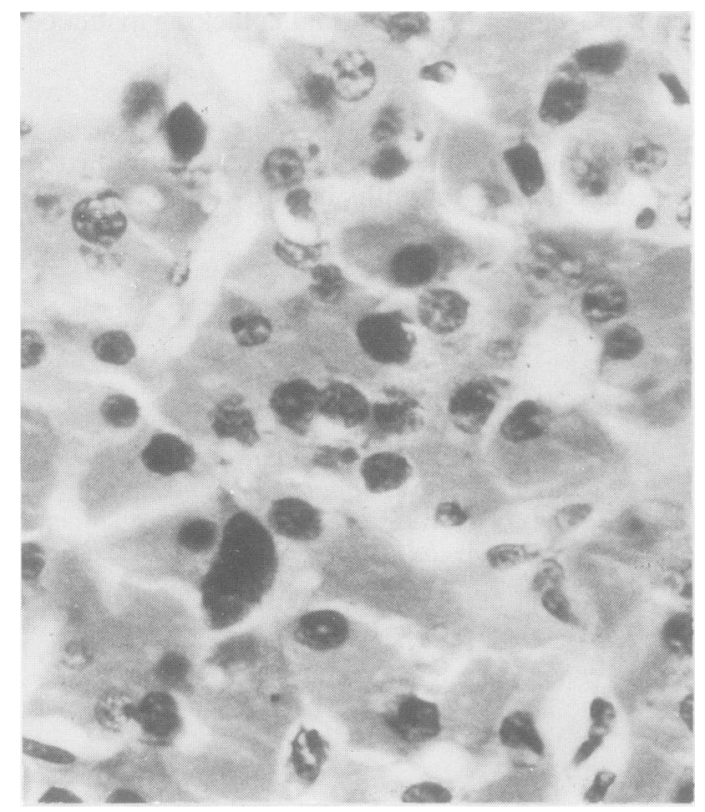

Fig. 9 Large hyperchromatic nuclei in an adenoma with some pleomorphism but no mitoses. Case 12. Haematoxylin and eosin $\times 320$. versity College Hospital with a plasma calcium con centration of $3.2 \mathrm{mmol} / \mathrm{l}$ and corneal calcification There was no evidence of bone disease. His erythro-cyte sedimentation rate was $4 \mathrm{~mm}$ in the first hour and alkaline phosphatase was $7 \mathrm{KA}$ units.

At operation a $2.7 \mathrm{~g}$ tumour adherent to the thyroid gland was resected with the right lobe of thyroid; three normal parathyroids were also shown. The tumour was firm with a fibrous capsule and bands splitting it into irregular areas. A trabecular architecture was present in places and a few mitoses were identified. Distinct infiltration of the resected thyroid lobe was seen (Fig. 5). Recovery was uneventful and no recurrence of parathyroid disease developed before his death from carcinoma of the lung in 1979 at the age of 77.

Comment: This was a clear case of carcinoma on the criteria, particularly because of the striking infiltration of the thyroid. Resection with the infiltrated thyroid cured the parathyroid disease.

\section{Case 12}

A 61 year old man became weak, tired, and thirsty. On examination he had a palpable nodule in the sternal notch and mild hypertension. Results of biochemical investigations were as follows: blood urea concentration $26 \mathrm{mmol} / \mathrm{l}$, plasma calcium concentration $4 \mathrm{mmol} / \mathrm{l}$, erythrocyte sedimentation rate $87 \mathrm{~mm}$ in the first hour. $X$ ray examination showed osteitis fibrosa with subperiosteal resorption cysts in 


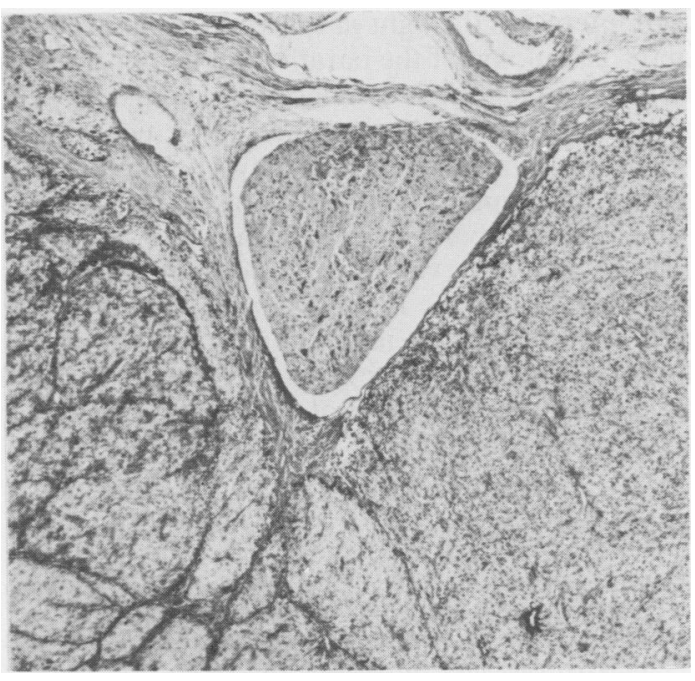

Fig. 10 Apparent invasion of vein. This section was from a $26 \mathrm{~g}$ tumour removed from a woman of 58 in 1963. There was no other feature to suggest carcinoma and it is thought to be an adenoma. No recurrence to date. Muscle is present in the wall of the vein.

the hands, "pepper pot" skull, teeth lacking lamina dura, and a single calculus in the right kidney.

At operation a soft adenoma $(0.5 \mathrm{~g})$ was removed from the site of the left upper parathyroid and a carcinoma $3.0 \mathrm{~cm}$ in diameter in the thymic fat and attached by a short band to the thyroid isthmus with extensions towards its lower poles was also removed
(Fig. 1). The thyroid was removed with the tumour and thymic fat. On section, the carcinoma was firm and white. It had a fibrous capsule and intersecting bands, which divided the tumour. There was a variegated architecture with a trabecular pattern in places (Fig. 3) and numerous mitoses were seen in some areas (Fig. 8). It infiltrated fibrous tissue to the margin of attached muscle but not the muscle itself.

The adenoma showed a picture with considerable variation in cell size, including large polypoid nuclei (Fig. 9) but most nuclei were smaller than in the carcinoma. No mitoses were seen in the adenoma. Two parathyroids on the right side were normal.

The postoperative course was stormy with severe oliguria, pulmonary embolism, and bronchopneumonia. But he was discharged well.

\section{Discussion}

Opinions differ about the diagnosis of carcinoma of the parathyroid by histological examination in the absence of infiltration or metastasis. One view is that this is not possible. ${ }^{8}$ However, Castleman and his associates, whose experience is considerable, have always maintained that is is possible. ${ }^{29}$ Review of the considerable material at University College Hospital supports his view. We have found the same features useful in making the diagnosis but emphasise the importance of considering the overall picture rather than a single criterion.

One problem is whether an adenoma can change to a carcinoma. Schantz and Castleman $1973^{9}$ state

Table 2 Clinical follow up

\begin{tabular}{|c|c|c|c|c|c|}
\hline Tumour group & Case No & Local recurrence & Metastases & Subsequent metabolic disease & $\begin{array}{l}\text { Death (time after } \\
\text { lst operation) }\end{array}$ \\
\hline \multirow[t]{2}{*}{ A } & $\begin{array}{l}3 \\
6\end{array}$ & $\begin{array}{l}\text { Yes } \\
\text { Yes }\end{array}$ & $\begin{array}{l}\text { Lumbar vertebra } \\
\text { Pulmonary }\end{array}$ & $\begin{array}{l}\text { Cushing's syndrome } \\
\text { Recurrent hyperparathyroidism } \\
\text { Successful surgery }\end{array}$ & 2 years \\
\hline & $\begin{array}{l}13 \\
19\end{array}$ & $\begin{array}{l}\text { Yes } \\
\text { Yes }\end{array}$ & $\begin{array}{l}\text { Lymph node } \\
\text { Pulmonary }\end{array}$ & $\begin{array}{l}\text { Recurrent hyperparathyroidism } \\
\text { Recurrent hyperparathyroidism }\end{array}$ & $\begin{array}{r}16 \text { years } \\
2 \text { years }\end{array}$ \\
\hline \multirow[t]{3}{*}{ B } & 12 & $\begin{array}{l}\text { Yes } \\
\text { Yes }\end{array}$ & $\begin{array}{l}\text { No } \\
\text { No }\end{array}$ & $\begin{array}{l}\text { Recurrent hyperparathyroidism } \\
\text { Recurrent hyperparathyroidism } \\
\text { Successful surgery }\end{array}$ & $\begin{array}{l}1 \text { year } \\
\text { Alive }\end{array}$ \\
\hline & 17 & Yes & No & $\begin{array}{l}\text { Recurrent hyperparathyroidism } \\
\text { Successful surgery }\end{array}$ & Alive \\
\hline & $\begin{array}{r}2 \\
4 \\
11 \\
10 \\
15\end{array}$ & $\begin{array}{l}\text { No } \\
\text { No } \\
\text { No } \\
\text { No } \\
\text { No }\end{array}$ & $\begin{array}{l}\text { No } \\
\text { No } \\
\text { No } \\
\text { No } \\
\text { No }\end{array}$ & $\begin{array}{l}\text { No } \\
\text { No } \\
\text { No } \\
\text { No } \\
\text { No }\end{array}$ & $\begin{array}{l}\text { Not known } \\
15 \text { years } \\
\text { Alive } \\
\text { Alive } \\
\text { Alive }\end{array}$ \\
\hline C & $\begin{array}{r}5 \\
7 \\
8 \\
9 \\
14 \\
16 \\
18 \\
20\end{array}$ & $\begin{array}{l}\text { Yes } \\
\text { Yes } \\
\text { Yes } \\
\text { No } \\
\text { No } \\
\text { No } \\
\text { No } \\
\text { No }\end{array}$ & $\begin{array}{l}\text { No } \\
\text { No } \\
\text { No } \\
\text { No } \\
\text { No } \\
\text { No } \\
\text { No } \\
\text { No }\end{array}$ & $\begin{array}{l}\text { Recurrent hyperparathyroidism } \\
\text { Recurrent hyperparathyroidism } \\
\text { No } \\
\text { No } \\
\text { No } \\
\text { No } \\
\text { No } \\
\text { No }\end{array}$ & $\begin{array}{l}12 \text { years } \\
1 \text { year } \\
11 \text { years } \\
7 \text { years } \\
\text { Alive } \\
\text { Alive } \\
\text { Alive } \\
\text { Alive }\end{array}$ \\
\hline
\end{tabular}

Details of cases 4 and 12 are in this paper, of case 3 in reference 7, and of case 6 in reference 6. 
that in none of their 67 cases was there evidence of origin of the carcinoma in a pre-existing adenoma or hyperplasia. In the AFIP Fascicle Castleman and Roth $^{2}$ indicate that only rarely does a tumour originally diagnosed as adenoma prove to be carcinoma with metastases to the lung after many years. In retrospect they were still unable to recognise any morphological criteria of carcinoma in the original tumour or in the metastases.

Of 20 cases recorded in this paper, four were initially diagnosed as adenoma in other hospitals; we were unable to examine the initial material in case 5 when investigation and treatment was undertaken at University College Hospital; in cases 6 and 8 we would have diagnosed carcinoma on our criteria; in case 13 we would have diagnosed adenoma on the initial biopsy but carcinoma in the recurrent and metastatic material.

In two cases there was histological evidence that the carcinoma had a uniform appearance with features similar to those in Figs. 3 and 8, but in one area the cells were smaller and similar to those of an adenoma. In this region a degenerate area with numerous cholesterol clefts suggested a lesion of longer duration than the main tumour. In case 9 the carcinoma was a firm white nodule in a multinodular tumour; abnormal cytology and increase in mitoses with an abnormal tripolar mitosis was confined to this area. Two other parathyroids showed slight nodular hyperplasia and one appeared to be normal. There was a history of radiation to the neck for exophthalmic goitre 53 years previously followed by 20 years of "radiation vomiting" and operation for a thyroid goitre 36 years after the radiation to the neck. This was the only case in the present series in which there was an indication of chief cell hyperplasia associated with carcinoma of the parathyroid.

Carcinoma associated with non-familial chief cell hyperplasia has been described at least once. ${ }^{10}$ Cases of carcinoma in familial hyperparathyroidism have also been recorded. ${ }^{1112}$ In some of these there was evidence of chief cell hyperplasia affecting other parathyroids. A first cousin of case 8 in the present series had an atypical adenoma resected in 1981; in neither patient 8 nor the cousin was there evidence of chief cell hyperplasia in other parathyroids. This is of interest in the light of the report of an adenoma and a carcinoma of the parathyroid in a brother and sister. ${ }^{13}$ Thus there is evidence that the parathyroids may be susceptible to genetic and environmental influences which may act initially to produce hyperplasia, hyperplasia with neoplasm, or neoplasia which may be benign or malignant.

It is not, however, the purpose of the present paper to discuss the implications of this or to compare it with malignancies in other tissues where similar relations are more obvious, but to state as clearly as possible the histological diagnostic problem of parathyroid malignancy.

\section{References}

' Castleman B. Tumours of the parathyroid glands. Atlas of tumor pathology. Washington DC: AFIP, 1952:50-9.

2 Castleman B, Roth SI. Tumors of the parathyroid glands. Atlas of tumor pathology. Washington DC: AFIP, 1978:74-82.

${ }^{3}$ Faccini JM. The ultrastructure of parathyroid glands removed from patients with primary hyperparathyroidism: a report of 40 cases, including four carcinomata. J Pathol 1970; 102: 189-99.

${ }^{4}$ Altenähr E, Saeger W. Light and electron microscopy of para thyroid carcinoma. Virchows Arch 1973;360:107-22.

5 Ghadially FN. Diagnostic electron microscopy of tumours. London: Butterworths, 1980:25-8.

- Davies DR, Dent CE, Ives DR. Successful removal of single metastasis in recurrent parathyroid carcinoma. $\mathrm{Br}$ Med 1973;i:397-8.

' Friedman M, Marshall-Jones P, Ross EJ. Cushing's syndromeadrenocortical hyperactivity secondary to neoplasms arisin outside the pituitary-adrenal system. $Q J$ Med 1966;35: 193-? 214.

${ }^{8}$ Pyrah LN, Hodgkinson A, Anderson CK. Primary hyperparathyroidism. Br J Surgery 1966;53:245-316.

- Schautz A, Castleman B. Parathyroid carcinoma: a study of 70) cases. Cancer 1973;31:600-5.

"Kramer WM. Association of parathyroid hyperplasia with neoplasia. Am J Clin Pathol 1970;53:275-83.

"Mallette LE, Bilezikian JP, Ketcham AS, Aurbach GD. Parathyroid carcinoma in familial hyperparathyroidism. Am J Med 1974;57:642-8.

${ }_{12}$ Dineen JS, Greenwood RH, Jones JH, Walker DA, Williams ED. Parathyroid carcinoma in familial hyperparathyroidism. $J$ Clin Pathol 1977; 30:966-75.

${ }^{13}$ Frayha RA, Nasser VH, Dagher F, Salt IS. Familial parathyroid carcinoma. Lebanese Medical Journal 1972;25:299-309.

Requests for reprints to: Dr JF Smith, 2 South Grove House, South Grove, Highgate Village, London N6, England. 